\title{
EMOTIONAL INTELLIGENCE AND ITS RELATIONSHIP WITH DEMOGRAPHIC CHARACTERISTICS AMONG NURSING STUDENTS
}

\author{
Shahnaz Salawati Ghasemi', Shima Farrokhi², Massoumeh Najafi3, Vahid Shojaeimotlagh ${ }^{4}$, Arezu Bozorgomid ${ }^{5}$, Mehdi Torabi ${ }^{6}$, \\ Fatemeh Yarahmadi ${ }^{7}$
}

${ }^{1}$ M. Sc. In Nursing, Instructor, Faculty of Nursing and Midwifery, Kurdistan University of Medical Sciences, Kurdistan, Iran. 2Instructor, Asadabad School of Medical Sciences, Asadabad, Iran.

3M. Sc. In Nursing, Faculty of Nursing and Midwifery, Tehran University of Medical Sciences, Tehran, Iran.

${ }^{4}$ Department of Medical Surgical Nursing, Khoy University of Medical Sciences, Khoy, Iran.

${ }^{5}$ Department of Medical Parasitology and Microbiology, School of Public Health, Tehran University of Medical Sciences, Tehran, Iran

${ }^{6}$ M. Sc. In Nursing, Faculty of Nursing and Midwifery, Urmia Faculty of Nursing, Urmia, Iran.

${ }^{7}$ M. Sc. In Nursing, Instructor, Department of Nursing, Borujerd Nursing Faculty, Lorestan University of Medical Sciences, Iran.

BACKGROUND ABSTRACT

As a significant field of study, nursing is one of the majors in which the role of multiple intelligences such as emotional intelligence seem more important compared to other fields of study. These intelligences have a remarkable impact on the nursing students' progress.

The present study was aimed at examining emotional intelligence and its relationship with demographic characteristics among nursing students.

\section{MATERIALS AND METHODS}

In the present descriptive study, 300 nursing students were selected by a simple randomly sampling method. The required data was retrieved from the students using Sharing Emotional Intelligence Scale and a demographic information questionnaire and analysed through descriptive statistics and correlational tests using SPSS 21.0.

\section{RESULTS}

The students' mean age was $21.37 \pm 2.39$ years. Most of the students were men $(55 \%)$ and juniors (30\%) (Semester 7 (17.1\%)). The mean (standard deviation) of emotional intelligence was 104.04 (13.75). Based on Pearson correlation coefficient, the correlation of age (0.084) and average (0.016) with the total score of emotional intelligence was low and there was no significant linear relationship between them $(\mathrm{p}>0.05)$. However, there was a significant positive relationship between age and the field of social skills with a correlation of coefficient of $0.127(p=0.032)$. Also, there was a significant positive relationship between average and the field of self-motivation with a correlation coefficient of $0.124(\mathrm{p}=0.037)$.

\section{CONCLUSION}

The students had an average emotional intelligence. It is recommended that students need to be provided with workshops aimed at boosting their emotional intelligence in order to promote academic levels among nursing students.

\section{KEY WORDS}

Emotional Intelligence, Demographic Characteristics, Students, Nursing.

HOW TO CITE THIS ARTICLE: Ghasemi SS, Farrokhi S, Najafi M, et al. Emotional intelligence and its relationship with demographic characteristics among nursing students. J. Evolution Med. Dent. Sci. 2018;7(30):3419-3422, DOI: $10.14260 /$ jemds/2018/771

\section{BACKGROUND}

Emotion is a psychological construct which consists of evaluating cognition, motives and situations. Emotional intelligence is needed to manage the emotions.[1] Emotional intelligence includes non-cognitive capabilities, knowledge and qualifications that enable an individual to adapt to different living conditions successfully.[2] Bar-on considers emotional intelligence as a pure factor in flourishing the individual's ability to succeed in life and believes that it is

'Financial or Other Competing Interest': None.

Submission 08-06-2018, Peer Review 04-07-2018,

Acceptance 11-07-2018, Published 23-07-2018.

Corresponding Author:

Shima Farrokhi,

Instructor,

Asadabad Nursing Faculty,

Asadabad, Hamadan, Iran.

E-mail: shahnaz.salawati68@gmail.com

DOI: $10.14260 /$ jemds $/ 2018 / 771$

\section{(c) $(1)$}

related to their emotional and mental health. He puts a lot of emphasis on interpersonal component in emotional intelligence. This component refers to the individual's ability to know and control their emotions and includes self-esteem, self-awareness, excitement, assertiveness, independence and self-actualisation.[3]

Nursing students are placed in a unique situation with regard to their impact on the phenomenon of health, because nursing is the profession of helping. Nurses need to have knowledge and skills to be able to predict situations and results. They should be able to think purposefully and create new ideas and evaluate them and they should be able to utilise useful information in judgements, decisions and problem solving. ${ }^{[4]}$ Various studies have shown that nursing students experience stress regarding academic programs and clinical environments.[5] Individuals with lower emotional intelligence adapt more poorly when they are faced with life stresses; therefore, they suffer from depression, despair and other negative outcomes more.[6] 
Moreover, different studies have indicated that numerous factors are related to emotional intelligence. Results of some studies show that the ability to express emotion and sympathy is more in women than men; however, some studies have reported that there is no difference between boys and girls regarding their emotional intelligence.[4] The results of the study conducted by Tehrani et al (2012) show that there is a relationship between emotional intelligence and mental health and academic achievement. They also reported that there was a significant relationship between emotional intelligence and educational semesters. ${ }^{[7]}$ As future nurses nursing students play a critical role in treatment teams; therefore, their role needs to be paid special attention. ${ }^{[8]}$ Since few studies have focused on this issue and there is a dire need to study emotional intelligence among nursing students, the researcher decided to concentrate on this important issue in a study entitled, "Emotional intelligence and its relationship with demographic characteristics among nursing students" in order to take an effective step forward to know the students' problems and help promote health of people and the society.

\section{MATERIALS AND METHODS}

The present descriptive study was carried out from August to January 2017 in Nursing Faculty, Kurdistan University of Medical Sciences. 300 individuals were taken for the study. The sample size was taken for convenience. Of the 300 students, 286 were analysed. The sampling method adopted is purposive sampling. The inclusion criteria were studying nursing B.Sc., lack of known mental disease and willingness to participate in the study. Exclusion criteria were lack of consent to continue participating in the study.

Data collection instruments were a demographic information questionnaire and Siberia Sharing Emotional Intelligence Scale. Siberia Sharing Emotional Intelligence Scale was designed by Siberia Sharing in 1999. It consists of subscales of self-motivation (7 items), self-awareness (8 items), self-control (7 items), social intelligence (6 items) and social skills (8 items). It is scored using a 5-point Likert scale (never $=5$ to always $=1$ ). Items that are underlined are inversely scored (never $=1$ to always- 5 ). The individual's scores range from 33 to 165 and higher scores indicate higher emotional intelligence. Farghdani (2003) reported the reliability and Cronbach's Alpha of the questionnaire as 0.78 and 0.74 , respectively. Namazi et al (2015) reported its validity as $0.63 .{ }^{[9]}$ In the present study, Cronbach's Alpha was utilised to determine the reliability of the questionnaires, which showed a reliability of 0.814 that is acceptable.

After necessary permissions were obtained from Kurdistan University of Medical Sciences and the Nursing and Midwifery Faculty, the researcher went to the students. After the introduction, letter was presented to the students. The objectives of the study were explained to them and written consent was retrieved from them. The study's instruments were distributed among the students and the collected data were analysed through descriptive and Pearson correlation and independent ' $\mathrm{t}$ ' tests using SPSS 21.0 at a confidence interval of 0.95 .

\section{RESULTS}

With regard to the students' individual characteristics, the results of the present study showed that the mean $( \pm$ standard deviation) of their age was $21.37( \pm 2.39)$. Most of the students were men (55\%), single (85\%) and the second child of their family (34.6\%). Also, most of the students resided in dormitory $(61.9 \%)$ and were seniors $(30 \%)$ (Semester 7 (17.1\%)). The students' mean emotional intelligence score was 104.04 (13.75).

\begin{tabular}{|c|c|c|c|c|}
\hline Variable & Min & Max & Mean & $\begin{array}{c}\text { Standard } \\
\text { Deviation }\end{array}$ \\
\hline $\begin{array}{c}\text { Emotional intelligence } \\
\text { (33-165) }\end{array}$ & 67 & 151 & 204.04 & 13.75 \\
\hline Self-motivation (7-35) & 13 & 35 & 21.79 & 3.35 \\
\hline Self-awareness (8-40) & 16 & 37 & 26.74 & 4.86 \\
\hline Self-control (7-35) & 10 & 35 & 21.14 & 3.56 \\
\hline $\begin{array}{c}\text { Social intelligence or } \\
\text { sympathy (6-30) }\end{array}$ & 9 & 30 & 18.83 & 3.76 \\
\hline Social skills (5-25) & 9 & 23 & 15.53 & 2.75 \\
\hline
\end{tabular}

Table 1. The Students' description based on their Emotional Intelligence Scores

\begin{tabular}{|c|c|c|c|c|}
\hline Variable & Frequency & $\begin{array}{c}\text { Frequency } \\
\text { Percentage }\end{array}$ & Mean & $\begin{array}{c}\text { Standard } \\
\text { Deviation }\end{array}$ \\
\hline $\begin{array}{c}\text { Emotional } \\
\text { intelligence } \\
(0-100)\end{array}$ & & & & \\
\hline Low (0-25) & 0 & 0 & 0 & 0 \\
\hline Average (25-75) & 277 & 96.90 & 52.91 & 9.24 \\
\hline High (75-100) & 9 & 3.10 & 81.73 & 2.99 \\
\hline \multicolumn{6}{|c|}{ Table 2. The Students' distribution based on their } \\
Emotional Intelligence \\
\hline
\end{tabular}

Based on Pearson correlation coefficient, the correlation of age (0.084) and average (0.016) with the total score of emotional intelligence was low and they did not have a significant statistical linear relationship ( $p>0.05$ ). However, age had a significant positive correlation with social skills with a correlation coefficient of $0.127(p=0.032)$. Also, there was a significant positive relationship between selfmotivation and average with a correlation coefficient of 0.124 $(p=0.037)$.

\begin{tabular}{|c|c|c|c|c|c|c|c|}
\hline \multirow{2}{*}{\multicolumn{2}{|c|}{ Variable }} & \multicolumn{6}{|c|}{ Emotional Intelligence } \\
\hline & & \multirow{2}{*}{ 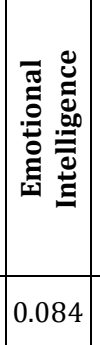 } & \multirow{2}{*}{ 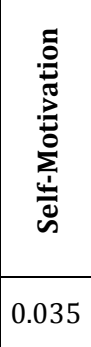 } & \multirow{2}{*}{ 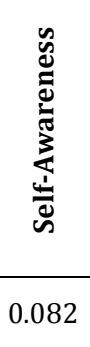 } & \multirow{2}{*}{ 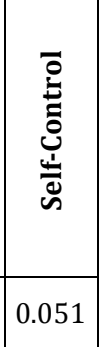 } & \multirow{2}{*}{ 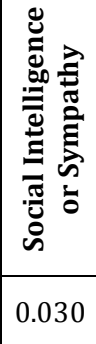 } & \multirow{2}{*}{ 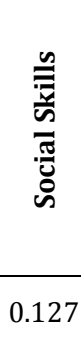 } \\
\hline Age & $\begin{array}{l}\text { Correlati } \\
\text { Coefficie }\end{array}$ & & & & & & \\
\hline \multirow{3}{*}{ Average } & $\begin{array}{c}\text { Probability } \\
\text { Amount }\end{array}$ & 0.154 & 0.558 & 0.166 & 0.388 & 0.617 & 0.032 \\
\hline & $\begin{array}{l}\text { Correlation } \\
\text { Coefficient }\end{array}$ & 0.016 & 0.124 & 0.001 & -0.010 & -0.033 & -0.015 \\
\hline & $\begin{array}{c}\text { Probability } \\
\text { Amount }\end{array}$ & 0.792 & 0.037 & 0.998 & 0.872 & 0.583 & 0.801 \\
\hline
\end{tabular}

According to the results of Independent T-test, the mean \pm standard deviation) of emotional intelligence scores in women (54.95 $( \pm 11.01))$ were significantly more than those of men (52.41 ( \pm 9.47$))(\mathrm{p}=0.039)$. In the areas of this scale, 
women obtained higher mean scores than men. Also, women obtained significantly higher scores in the area of selfmotivation $(p=0.003)$ than men. Emotional intelligence scores were higher among the single students (54.33 $( \pm 10.95)$ ) than the married ones (50.93 $( \pm 5.83))$. This difference as shown by the results of Independent T-test was significant $(p=0.003)$. In the areas of this scale, the single students also obtained higher scores than the married students. Moreover, compared to the married students, the single students obtained significantly higher scores in the areas of self-awareness $(\mathrm{p}=0.001)$ and social intelligence $(\mathrm{p}=0.041)$.

\begin{tabular}{|c|c|c|c|c|c|}
\hline $\begin{array}{c}\text { Variable (0- } \\
100)\end{array}$ & Gender & Mean & $\begin{array}{l}\text { Standard } \\
\text { Deviation }\end{array}$ & \begin{tabular}{|c|} 
Test \\
Statistic
\end{tabular} & $\begin{array}{c}\text { Probability } \\
\text { Amount }\end{array}$ \\
\hline \multirow{2}{*}{$\begin{array}{l}\text { Emotional } \\
\text { Intelligence }\end{array}$} & Man & 52.41 & 9.47 & \multirow{2}{*}{2.07} & \multirow{2}{*}{0.039} \\
\hline & Woman & 54.95 & 11.01 & & \\
\hline \multirow{2}{*}{$\begin{array}{c}\text { Self- } \\
\text { Motivation }\end{array}$} & Man & 50.53 & 10.62 & \multirow[t]{2}{*}{2.97} & \multirow{2}{*}{0.003} \\
\hline & Woman & 54.70 & 12.68 & & \\
\hline \multirow{2}{*}{$\begin{array}{c}\text { Self- } \\
\text { Awareness }\end{array}$} & Man & 56.69 & 13.11 & \multirow[t]{2}{*}{1.94} & \multirow{2}{*}{0.060} \\
\hline & Woman & 60.08 & 16.58 & & \\
\hline \multirow{2}{*}{$\begin{array}{c}\text { Self- } \\
\text { Control }\end{array}$} & Man & 49.33 & 11.81 & \multirow{2}{*}{1.42} & \multirow{2}{*}{0.158} \\
\hline & Woman & 51.46 & 13.39 & & \\
\hline \multirow{2}{*}{$\begin{array}{c}\text { Social } \\
\text { Intelligence } \\
\text { or Sympathy }\end{array}$} & Man & 53.03 & 15.66 & \multirow[b]{2}{*}{0.39} & \multirow[b]{2}{*}{0.691} \\
\hline & Woman & 53.77 & 15.72 & & \\
\hline \multirow{2}{*}{$\begin{array}{l}\text { Social } \\
\text { Skills }\end{array}$} & Man & 51.76 & 13.74 & \multirow{2}{*}{1.02} & \multirow{2}{*}{0.311} \\
\hline & Woman & 53.42 & 13.77 & & \\
\hline
\end{tabular}

Table 4. The Relationship between Gender and Emotional Intelligence among the Students under Study

\begin{tabular}{|c|c|c|c|c|c|}
\hline $\begin{array}{c}\text { Variable (0- } \\
100) \\
\end{array}$ & Gender & Mean & \begin{tabular}{|c|} 
Standard \\
Deviation \\
\end{tabular} & \begin{tabular}{|c|} 
Test \\
Statistic \\
\end{tabular} & $\begin{array}{c}\text { Probability } \\
\text { Amount }\end{array}$ \\
\hline \multirow{2}{*}{$\begin{array}{l}\text { Emotional } \\
\text { Intelligence }\end{array}$} & Single & 54.22 & 10.95 & \multirow{2}{*}{2.99} & \multirow{2}{*}{0.003} \\
\hline & Married & 50.93 & 5.83 & & \\
\hline \multirow{2}{*}{$\begin{array}{c}\text { Self- } \\
\text { Motivation }\end{array}$} & Single & \begin{tabular}{|l|}
53.04 \\
\end{tabular} & 12.44 & \multirow{2}{*}{0.88} & \multirow{2}{*}{0.379} \\
\hline & Married & 51.66 & 8.79 & & \\
\hline \multirow{2}{*}{$\begin{array}{c}\text { Self- } \\
\text { Awareness }\end{array}$} & Single & \begin{tabular}{|l|}
59.54 \\
\end{tabular} & 15.76 & \multirow{2}{*}{3.56} & \multirow{2}{*}{0.001} \\
\hline & Married & 53.05 & 9.92 & & \\
\hline \multirow{2}{*}{ Self-Control } & Single & 50.79 & 13.19 & \multirow{2}{*}{0.88} & \multirow{2}{*}{0.375} \\
\hline & Married & 48.92 & 9.69 & & \\
\hline \multirow{2}{*}{$\begin{array}{c}\text { Social } \\
\text { Intelligence } \\
\text { or Sympathy }\end{array}$} & Single & 54.23 & 16.03 & \multirow[b]{2}{*}{2.06} & \multirow[b]{2}{*}{0.041} \\
\hline & Married & 48.93 & 12.63 & & \\
\hline \multirow{2}{*}{ Social Skills } & Single & 52.83 & 14.09 & \multirow{2}{*}{0.48} & \multirow{2}{*}{0.631} \\
\hline & Married & 51.74 & 11.74 & & \\
\hline
\end{tabular}

\section{DISCUSSION}

The present study was carried out in order to examine the relationship between emotional intelligence and demographic characteristics among nursing students. Most of the students in the present study had an average level of emotional intelligence (54.5\%). In their study aimed at assessing the level of emotional intelligence and self-esteem in nursing and midwifery students of Mazandaran University of Medical Sciences, Jannati et al (2010) concluded that $13.8 \%, 71.7 \%$ and $14.5 \%$ of the students had respectively high, average and low emotional intelligence. In other words most of the students had average emotional intelligence which was also observed in the present study and in this regard the two studies are in agreement. Similarity between the populations of the two studies (Nursing students) can be the reason for this similarity of results. Ghaderi et al (2014) studied emotional intelligence among students of Ahvaz
Universities. They studied 303 students and the results of their study showed that most of the students had average emotional intelligence (77.23\%).[10] In contrast to the results of the present study were the results of the study carried out by Chinipardaz et al (2011),[11] who studied emotional intelligence and its relationship with academic achievement among medical students of Tehran University of Medical Sciences. The medical students' average emotional intelligence in all 15 subscales was below the defined standard. This discrepancy can be attributed to the difference between the target groups and the sample size. The present study was carried out on nursing students, while Chinipardaz et al studied medical students. Also, the results of the study carried out by Shahbazi (2012) showed that the nursing students' emotional intelligence level was not standard, because there was no systematic training for that, but it can be enhanced by focusing on it[12] which is not in agreement with the present study.

In the present study there was a correlation between the students' social skills, as an area of emotional intelligence and age, such that older students had higher social skills. Shaughnessy and Parker[13] and Brown and Moshavi[14] stated that higher age groups have higher emotional intelligence than lower age groups. Moreover, Benson et al[15] pointed out that the nursing students' emotional intelligence increased from the first year to the fourth year of education. Given the characteristics mentioned for emotional intelligence, it is expected that emotional intelligence rises with an increase in the individual's age and exposure to educational and occupational situations and different individuals and cultures. In the present study, the female students' emotional intelligence was significantly higher than that of the male students. The results of the review study carried out by Naghavi and Redzuan indicated that girls had higher emotional intelligence than boys. According to the authors, compared to boys girls express their feelings more and cultural and belief differences of the society can affect this issue.[16] In studies carried out on the relationship between gender and emotional intelligence by Molaei et al[4] and Ghaedi et al, the total score of emotional intelligence had a significant relationship with gender and the areas of selfcontrol, self-awareness and sympathy significantly differed with gender such that they were higher among girls than boys.

In the present study, there was no significant statistical relationship between the students' average and their emotional intelligence scores. It seems that students with higher averages use their cognitive intelligence more than emotional intelligence. Shipley et al also stated that students with higher academic scores are more reliant on their cognitive intelligence and those with average GPA depend more on their emotional intelligence.[17]

It is recommended that further studies should be carried out in order to understand barriers to promotion of emotional intelligence among students. Also, it is suggested that students of other fields of study should be studied and compared with nursing students. In order to obtain more precise results and generalise them to the community of nursing students, future studies need to be carried out on larger samples. Since the questionnaires were filled out by self-report method, students might not have paid sufficient 
attention, while answering the questions, which is one of the limitations of the present study.

\section{CONCLUSION}

In the present study, there was a correlation between emotional intelligence and some demographic characteristics. Nowadays, educating human resources is the most important component of higher education and the most outstanding factor in national development. Student community is one of the largest groups of the society. Students and particularly nursing students who often deal with clients and patients that require strong support and communications need to be spiritually and mentally prepared, so that they can accept this role with sufficient adequacy and trust. It is essentially important to pay attention to emotional intelligence and communication skills of this group of students in order to promote their scientific and practical capacity and academic achievement. According to the results of the present study, suitable measures need to be taken in order to enhance emotional intelligence among nursing students.

\section{ACKNOWLEDGEMENTS}

The present study was retrieved from a research project approved by the Research Council of Kurdistan University of Medical Sciences and Health Services. This project is registered in the Ethics Committee under the ID IR.MUK.REC.1396/145. The authors would like to sincerely thank the honourable research deputy, dear faculty members of the Nursing Department and dear students of Nursing and Midwifery Faculty.

\section{REFERENCES}

[1] Gupta S. Emotional intelligence for students. Journal of Teaching English for Specific and Academic Purposes 2014;2(1):143-6.

[2] Parker JDA, Summerfeldt LJ, Hogan MJ, et al. Emotional intelligence and academic success: examining the transition from high school to university. Personality and Individual Differences 2004;36(1):163-72.

[3] Bar-On R. The Bar-On model of emotional-social intelligence (ESI). Model overview retrieved from the Consortium for Research on Emotional Intelligence in Organizations website. Psicothema 2006; (Suppl 18):13-25.

[4] Molaei E, Asayesh H, Taghvakish B, et al. Gender difference and emotional intelligence in Golestan university of medical sciences' students. Journal of Gorgan Bouyeh Faculty of Nursing \& Midwifery 2012;8(2):30-4.

[5] Por J, Barriball L, Fitzpatrick J, et al. Emotional intelligence: Its relationship to stress, coping, wellbeing and professional performance in nursing students. Nurse Education Today 2011;31(8):855-60.

[6] Salovey P, Mayer JD, Caruso D, et al. Chapter 11: The positive psychology of emotional intelligence. Counterpoints 2008;336:185-208.
[7] Tehrani H, Kabir NK, Sheraghi F, et al. The Relationship between emotional intelligence, mental health and academic achievement in Neyshabour nursing students. Sci J of Hamadan Nurs Midwifery Fac 2012;20(3):35-45.

[8] Montes-Berges B, Augusto JM. Exploring the relationship between perceived emotional intelligence, coping, social support and mental health in nursing students. Journal of Psychiatric and Mental Health Nursing 2007;14(2):163-71.

[9] Namazi A, Alizadeh S, Kouchakzadeh-Talami S. The correlation between general health, emotional intelligence and academic achievement together on midwifery students. Journal of Clinical Nursing and Midwifery 2015;4(2):20-8.

[10] Ghaderi M, Nasiri M, Zakeri Y, et al. Assessment of emotional intelligence in Ahvaz Universities students in 2014. Journal of Rafsanjan University of Medical Sciences 2015;14(5):379-92.

[11] Chinipardaz Z, Boroujerdni GM, Pasalar P, et al. Investigation of emotional intelligence and its relationship with academic achievement in medical students of Tehran University of medical sciences in 2008-2009. Strides in Development of Medical Education, J of Medical Education Development Center 2012;8(2):167-72.

[12] Shahbazi S, Hazrati M, Moattari M, et al. Training problem solving skills and its effect on emotional intelligence of nursing students of Shiraz. Iranian J of Medical Education 2012;12(39):67-76.

[13] Shaughnessy P, Parker J. Promoting emotional intelligence: an intervention program for use in different aboriginal groups. Invited address at the annual meeting of the, National Consultation on Career Development (NATCON), annual meeting of The National Consultation on Career Development (NATCON), Ottawa, Ontario 2005.

[14] Brown FW, Moshavi D. Transformational leadership and emotional intelligence: a potential pathway for an increased understanding of interpersonal influence. Journal of Organizational Behavior 2005;26(7):86771.

[15] Benson G, Ploeg J, Brown B. A cross-sectional study of emotional intelligence in baccalaureate nursing students. Nurse Education Today 2010;30(1):49-53.

[16] Naghavi F, Redzuan M. The relationship between gender and emotional intelligence. World Applied Sciences Journal 2011;15(4):555-61.

[17] Shipley NL, Jackson MJ, Segrest SL. The effects of emotional intelligence, age, work experience and academic performance. Research in Higher Education Journal 2010;(9):1-18. 